特集：生体防御に関わる蛋白質

\title{
生体防御に関わる蛋白質
}

\author{
藤 田 博 美 \\ 北海道大学大学院医学研究科環境医学
}

\section{Proteins in Response to Environmental Stress}

\author{
Hiroyoshi FUJITA \\ Laboratory of Environmental Biology, Hokkaido University School of Medicine, Sapporo
}

\begin{abstract}
Last decade, remarkable progress was achieved in the field of environmental sciences, especially those related to biological functions against environmental stress. Recent progress has been focused on the transcriptional control of proteins, such as cytochrome P450, UDP-glucronosyltransferase, and metallothionein. Along with these studies, entirely new functions of some proteins were identified; for example heme oxygenase-1, originally isolated by the catalytic activity of heme, is nowadays recognized as one of the stress proteins. We are, therefore, interested in the relationship among proteins of body defense mechanisms; i.e., co-regulation of two (or more) distinct proteins, and why they should be under the same regulation.

One possible idea is that they are members of the defense system against active oxygen, which will be described by Drs. Sato and Inoue in a future review. Alternatively, they might have evolved from an ancestor of the defense system that originally protected from oxygen toxicity. Findings on AhR/Arnt and HIF1 systems demonstrating that they are members of the same PAS family seem to support this hypothesis. One of the missing links of the hypothesis is the so called oxygen sensor, suggesting (a) hemoprotein in $1988^{4)}$. A review by Dr. Ogawa on Bach1, the first vertebrate transcription factor controlled by heme, will provide on answers to the missing links.

Through this series of reviews, we have a rough map of the biological system against environmental stress to explore the new frontier of environmental science.
\end{abstract}

\begin{abstract}
衛生学あるいは環境医学一中毒学研究の一つの特徴 は，ある事件が起きた後の事象の解明という点にある。 水俣病, イタイイタイ病, 四日市喘息などのいわゆる公 害時代の研究はそうした解析によって行われてきたし, 今後も社会医学的な事件の発生のたびにこのような解析 が行われることになると考えられる。このような研究が 社会に対する直接的な貢献になることは確かであるが, 一方では研究を行う上での主体性や一貫性が見失われて しまう可能性も否定できない。後継研究者の養成機関で あると云う大学の本質を鑑みれば, 研究の流れが将来に
\end{abstract}

受付 2001 年 11 月 1 日, 受理 2001 年 11 月 20 日

Reprint requests to: Hiroyoshi FUJITA

Laboratory of Environmental Biology, Hokkaido University School of Medicine, North 15, West 7, Kita-ku, Sapporo 060-8638, Japan

Phone: +81(11)706-5066

FAX: +81(11)706-7819

E-mail: alfujita@med.hokudai.ac.jp
どのような発展性を持つものであるかということも重要 なポイントであり, 直接的な社会への成果還元を越えた 研究の座標軸も必要であろう。

では，どのような座標軸を設定することができるだろ うか?「生命は環境なくしては存在しえない（存在しえ なかった)」という極めて当り前の事実から一つの可能性 を導くことができるのではないだろうか? 即ち, 我々の 体と環境の間で起きること, 引き起こされる可能性のあ るもろもろの出来事は, 全て生命の歷史の中で, 我々の 祖先と環境の間で引き起こされた応答を祖形としてお り, 恐らくは生物機構の進化によって多くの環境要因に 対応できるような多様性が獲得されてきたのであろう。 (生物学的多様性を獲得した典型例として, 第一相反応を 司るシトクロム $\mathrm{P} 450^{1)}$, 第二相反応を司る UDP-グルクロ ン酸トランスフェラーゼ2) を上げることができよう)。 ここに上げたような環境応答に関わる遺伝子進化を明 


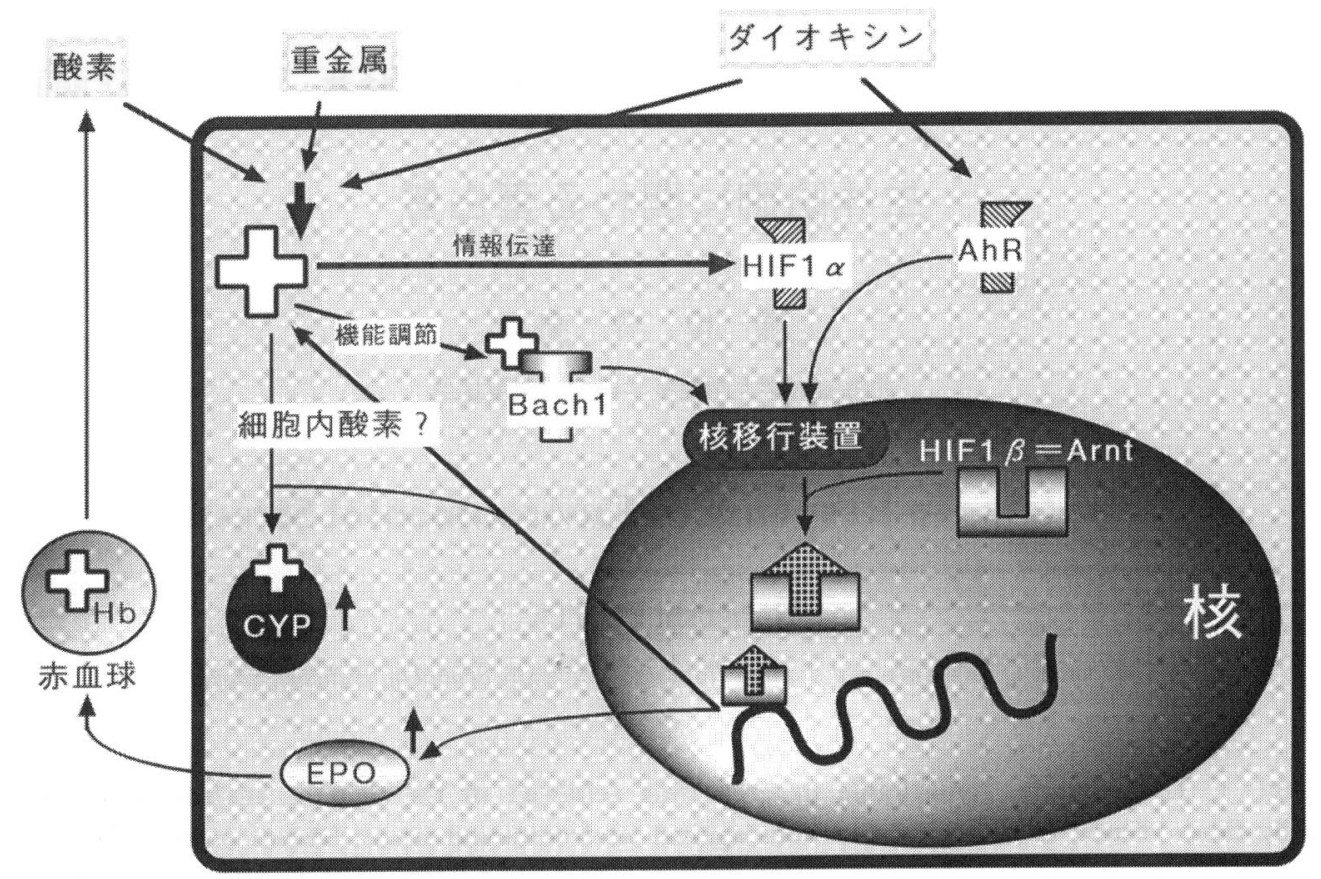

細胞内環境応答系の模式図

環境中のダイオキシンや酸素の情報は共通ないし同種類の蛋白質を介して核に伝達される。EPO: エリスロポエチン, CYP シトクロム P450, §: ヘム

らかにし，そのコードする個々の蛋白質の機能としての 環境応答反応を記載するという営みが, これまでの環境 科学研究の主要テーマの一つであった。では, この次に 来るべきものは何であろうか?一つの可能性は, 個別の 環境応答機構を統合するような視線ではないだろうか。 言い換えれば個々の応答の中から共通する要素を抽出す ることができれば，それは恐らくは環境応答機構の一つ の本質と密接に繋がっている可能性が高いのではない 力。

一例として上げるとすれば，我々の直接の祖先である 酸素下で生存しうる生命の誕生は，一方では酸素を用い た高エネルギー反応を利用した進化へと生命史を導いた が，他方では酸素が本来持っている毒性からどのように 生命自身を守るかという，大きな課題を突きつけること になった。このことからは, 我々が現在目にしている中 毒現象, あるいは中毒に対する生体応答そのものの祖形 を，生命が酸素に対してどのように対応してきたかとい う一点から捉えうるという仮定も可能である。

実際に 1980 年代から研究が進んだ環境因子ダイオキ シンに対する生体防御系を構成する転写因子 AhR/Arnt ヘテロダイマーと 90 年代から急速に解析が進んだ酸素 応答に関与する転写因子 HIF $\alpha / H I F \beta$ へロダイマーにつ いて, 極めて興味深いことが広く知られている (図)。す なわちこれらは全て PAS 蛋白質と呼ばれるグループに 属寸る同種の蛋白質であること, さらには HIF そのものであることが明らかになった。言い換えれば同 種のダイオキシンに関する情報を受け取る AhR と酸素 に関する情報を受け取る HIF $\alpha$ は同種類の蛋白質であり,
かつ Arnt 即ち HIF $\beta$ とへテロダイマーを形成する時点に おいて競合する ${ }^{3)}$ 。しかも，酸素センサーであるへム ${ }^{4)}$ に関しては，ダイオキシンはへム合成を阻害し5)代表的 なシトクロム P450 の合成を誘導することによって ${ }^{3)}$, 調 節性へム（ないしは遊離へム）の濃度を低下させるよう に作用することにより，やはり両者の情報は競合してい る。

このような競合が起きた原因として, 我々は酸素とダ イオキシンはともに本来は生体毒であり, 生命史上同時 期に誕生したということに行き当たらざるを得ない。考 えてみれば，地球上に自然に存在するものは塩素を含ん でいる。ということは，それらが燃える条件を地球が満 たすことは，ダイオキシンが地球上に発生することとぼ ぼ同義である。燃焼のための条件は，誰でも知っている ように酸素が存在することである。植物の祖先によって この地球上に酸素が産まれたということは, ダイオキシ ンの発生が間近であるあることを意味している。猛毒の 酸素とダイオキシン，この二つの物質から身を守るため の防御系を生命が工夫し始めたことが，両者に対する生 対防御系が近縁のものや共通のもので構成されているこ とによって示されているのではないか。

とするならば, このような防御系の本質を担うものは 何であろうか? 酸素の存在以前から生命体に利用されて きたへムが，酸素の検知機構としての機能をも持ち始め たことが本質の一つであろうと考えて, 我々は環境の条 件を生命に伝えるためのへムを利用する装置, 即ち転写 系について研究を行ってきた。もちろん酵母においては へムが調節因子となっている転写因子 Hap1 の存在が古 
くから知られてきたが, 高等動物においては全く不明で あり，また Hap1 類似の蛋白質の検索も全て成功してい なかった。今回，ようやく哺乳類においてへムによる調 節を受ける転写因子 Bach1 を同定することが出来た ${ }^{6)}$ 。 詳細は，解析を担当した小川の総説に譲るが，この発見 により我々がかねてから提案してきた環境応答機構の本 格的な解析が進むことになると考えている。

さて，本特集と同じ「生体防御に関わる蛋白質」とい うタイトルのチャプターをもつ「Toxicology Today: 中毒 学から生体防御の科学へ」という教科書を世に送ったの は 1994 年の春のことである7)。幸いにも時を経ずに完売 となった同書の改訂版の話は何度か出ながら，お互いの 日常の余りの多忙さを理由に先送りになっている。しか しながら，環境医学，特に環境応答機構の解明は近年極 めて急速に進歩しており，少なくとも「生体防御に関わ る蛋白質」については内容を新たにしておきたいと念願 していた。幸い, 衛生学雑誌編集部において, このよう な領域に関する総説を緾めることについての賛同が得ら れたこともあり, 今回の特集号を刊行する運びとなった。

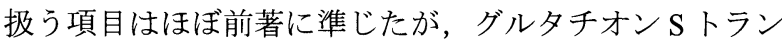
スフェラーゼについては編者の手違いで入稿が遅れたの で, なるべく近い衛生学雑誌に掲載することとしたい。

\section{参考文献}

1) Yoshida Y, Aoyama Y. The P450 superfamily: A group of versatile hemoproteins contributing to the oxidation of various small molecules. In: Fujita H, editor. Regulation of Hemoprotein synthesis. Ohio: AlphaMed, 1994: 75-88.

2) Sato H, Aono S, Danos O, Heard JM, Koiwai O. BilirubinUDP-glucuronosyltransferase: Genetic defect of the hyperbilirubinemic Gunn rat, a model of Crigler-Najjar syndrome type I. In: Fujita H, editor. Regulation of Hemoprotein synthesis. Ohio: AlphaMed, 1994: 117-123.

3）十川和博. PAS 蛋白質の構造と機能. 生化学 1995；67： 1283-1287.

4) Goldberg MA, Dunning SP, Bunn HF. Regulation of erythropoietin gene: Evidence that the oxygen sensor is a heme protein. Science 1988; 242: 1412-1415.

5) Sassa S, Fujita H, Sugita O. Genetic regulation of the heme pathway. Ann New York Acad Sci 1988; 514: 15-22.

6) Ogawa K, Sun J, Taketani S, Nakajima O, Nishitani C, Sassa S, Hayashi N, Yamamoto M, Shibahara S, Fujita H, Igarashi $\mathrm{K}$. Heme mediate derepression of Maf recognition element through direct binding to transcription repressor Bach1. ENBO J 2001; 20: 2835-2843.

7）佐藤 洋編, Toxicology Today 一中毒学加生体防御 の科学へ一, 京都：金芳堂, 1994；259-349. 